\title{
CRÉDITOS DE PRÉ-REQUISITO: SÃO BASÍLIO E SEU DISCURSO AOS JOVENS SOBRE AS LETRAS GREGAS
}

\author{
Bruno Salviano Gripp*
}

Recebido em: 07/03/2019

Aprovado em: 11/05/2019

RESUMO: O Discurso aos Jovens sobre como tirarproveito das Letras Gregas de
Basílio de Cesareia é um texto de enorme importância histórica e serviu,
sobretudo no Renascimento, como texto de justificativa para a adoção
da literatura pagã em meios cristãos. Este artigo faz uma análise do texto
centrando-se em primeiro lugar na idade do público com que Basílio
fala, para depois compreender de forma mais correta os objetivos que o
autor tem ao fazer essa alocução. Chegamos à conclusão de que o texto é
dirigido a jovens que cursam a chamada escola do $\gamma \rho \mu \mu \mu \alpha \tau$ chń , ou aquilo
que Marrou chamou de "ensino secundário", e possuem entre 12 e 16
anos de idade. Com isso, Basílio julga que a literatura grega pode ser um
importante trampolim para a aquisição das disposições morais necessárias
para a posterior compreensão do texto bíblico e das doutrinas sagradas.

PALAVRAS-CHAVE: Basílio de Cesareia; literatura grega; educação.

PREREQUISITES: BASIL OF CAESAREA AND HIS ADDRESS TO THE YOUNG IN THE UTILITY OF GREEK LITERATURE

\begin{abstract}
Basil of Caesarea's Address to the Young on how to take profit from Greek Letters has had an enormous impact and has served, especially in the Renaissance, as a reason for the adoption of Greek pagan literature in a Christian society. This paper analyses its text focusing in a first moment on the age of the public addressed by Basil. In a second moment, it tries to understand more precisely the goals of the author in this discourse. We conclude that the writing directs itself to young attending a $\gamma \rho \alpha \mu \mu \alpha \tau \imath \sigma \tau$ ' or what Marrou called "secondary school," with about 12 or 16 years old. Basil then considers that Greek literature can be an important springboard to the acquisition of the required moral dispositions to the later comprehension of the biblical text and the sacred doctrines.
\end{abstract}

KEYWORDS: Basil of Caesarea; Greek Literature; Education. 
$\mathrm{E}$ m todo o cristianismo antigo, poucos textos trataram diretamente da relação entre a religião que nascia e se afirmava no contexto do Império Romano tardio e a cultura greco-romana que moldou essa civilização. ${ }^{1}$ De modo geral, os autores cristãos ficam em silêncio em relação a essa questão, e a atitude explícita de Agostinho de Hipona é uma raridade entre os padres da Igreja. ${ }^{2}$ Mais característica é a atitude de Gregório de Nissa, que em apenas um tratado, o Diálogo sobre a alma e a ressurreição, se dedica a comentar as doutrinas sobre a alma das escolas filosóficas gregas, mas ao longo de todo o restante de sua obra, não faz menção direta a nenhum pensador ou escola antiga, ainda que esteja trabalhando com várias de suas ideias. ${ }^{3}$

A exceção mais importante para esse silêncio é o Discurso aos jovens sobre como tirar proveito das letras gregas de Basílio de Cesareia. Esse texto é um dos mais estudados do período e, caso raro para essa época, é um dos poucos a contar com mais de uma edição crítica, ${ }^{4}$ e já conta com um número considerável de estudos. ${ }^{5} \mathrm{O}$ opúsculo obteve grande sucesso desde a Antiguidade, tendo sido traduzido para o siríaco e o árabe (Fedwick, 1981, p. 450), sobretudo gozando de enorme popularidade a partir do Renascimento (Backus, 2017, p. 36).

\section{QUEM SÃo “OS JOVENS”?}

O texto é dirigido aos "jovens," no título " $\pi \rho$ ò da carta já houve alguma discussão, ${ }^{6}$ a interpretação tradicional diz que ela se destina aos sobrinhos do autor, e há diversas passagens em que o texto dá claras impressões de seguir neste ponto, quando afirma:

\footnotetext{
${ }^{1}$ A respeito do relacionamento entre a cultura clássica e o cristianismo nascente destaco as obras de Jean Daniélou (1961), Werner Jaeger (1991), Hugo Rahner (2011) e, aqui no Brasil, Jacyntho Brandão (2014).

${ }^{2}$ Sobre a relação entre Santo Agostinho e a cultura clássica, em uma vasta bibliografia, destaco as obras de Henri Irenée Marrou (1949) e Hugo Langone (2018).

${ }^{3}$ Sobre a formação filosófica de Gregório de Nissa, foi durante os primeiros anos de estudo da obra do autor um passatempo bastante popular entre os estudiosos investigar as origens gregas das diversas doutrinas que nela aparecem. Sobre isso ver, dentre outros, Daniélou (1956), Hans Urs von Balthasar (1942), Edward Mühlenberg (1971) para exemplos dessa atividade. Ademais, a formação retórica é um aspecto importante da obra de Gregório; ver os estudos de Morwenna Ludlow (2007) e Martin Esper (1982), que mostram como Gregório faz uso das técnicas retóricas de sua época.

${ }^{4}$ São as edições de Mario Naldini (1984), Wilson (1975) e Boulanger (1935).

${ }^{5}$ Destaco, além das introduções das edições críticas, os comentários de Raymond van Dam (2002), Philip Rousseau (1998), Ernst Fortin (1981), Mario Naldini (1978), Ernesto Valgiglio (1975) e Ann Moffat (1972).

${ }^{6}$ Moffat (1972) rejeita essa identificação, ao passo que Naldini (1978; 1984), tende a aceitar esses sobrinhos como parte de sua audiência, interpretação que tende a ser seguida por van Dam (2002) e Rousseau (1998).
} 
E pela familiaridade natural eu me encontro logo depois dos seus pais, a ponto de eu partilhar um pouco da benevolência paterna, e considero que vocês, se não me enganar na impressão, não sentem falta dos parentes ao olharem para mim. ${ }^{7}$

No entanto, há quem discorde dessa afirmação, preferindo ver nas alocuções de Basílio somente lugares comuns em que ele, como presbítero - na opinião de Moffat inclusive com apenas trinta anos de idade -, tem cuidado pastoral com seu rebanho (Moffat, 1972, p. 81). Ou seja, o presbítero - pois, se seguirmos a datação mais precoce do tratado, é de um período em que Basílio ainda não fora consagrado como bispo - coloca-se na posição de pai substituto desses jovens que estão sob seus cuidados.

Não pretendo me aprofundar nessa discussão sobre a ocasião desse texto, porque de certo modo ela é insolúvel, devido à falta de dados que o texto nos fornece. Mas ela põe em destaque o destinatário dessa alocução e isso é um ponto importante para a compreensão do tratado como um todo. O texto frequentemente se dirige para seu público e trava um diálogo constante com ele. Dessa maneira recebemos algumas informações que não é sempre que possuímos na homilética do autor e dos outros padres capadócios.

\subsection{A idAde de HÉracles Na ALEgoria de PRódico}

A respeito da idade, em um momento posterior, ao comentar sobre a alegoria de Héracles e a Virtude de Pródico de Ceos, Basílio dá uma informação importante a respeito da idade de seu público: "quando Héracles era bastante jovem, e tendo quase a mesma idade que vocês agora possuem". ${ }^{8}$ Ora, a fonte de onde Basílio retirou essa história, direta ou indiretamente, é Xenofonte, e o texto original é bastante explícito a respeito da idade de Héracles no momento desse encontro: "Pois diz que Héracles, quando seguia da infância para a juventude, na idade em que os jovens, ao se tornarem autossuficientes, mostram se haverão de se voltar em sua vida para o caminho da virtude ou do vício [...]."9

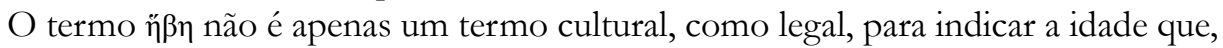
na maioria das cidades da Antiguidade, os jovens começavam os rituais para se tornarem adultos. Na Atenas pós-clássica esse serviço é chamado de efebia (Marrou, 1991, p. 168ss), mas ele se faz presente em diversos ambientes no mundo antigo (Marrou, 1991, p. 363), e a idade precisa em que isso acontecia em Atenas é incerta, por termos fontes um pouco desencontradas: o Etymologicum Magnum afirma que se dava aos 16 anos, ${ }^{10}$ as Expressões

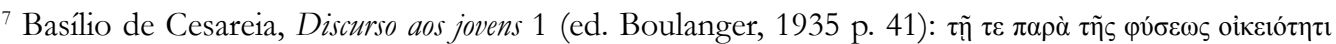

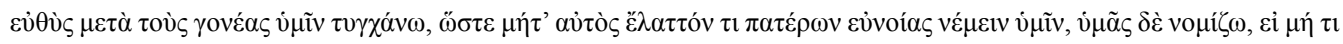

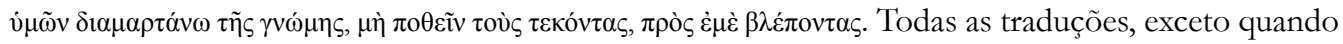
explicitamente informado, são de minha autoria.

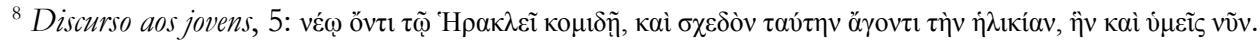

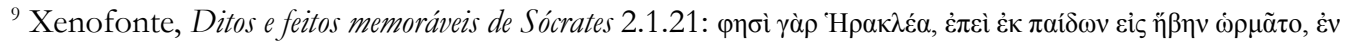

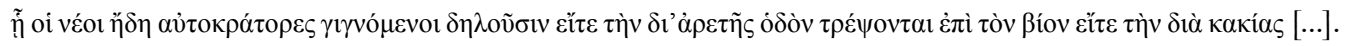
${ }^{10}$ Etymologicum Magnum, p. 359.
} 


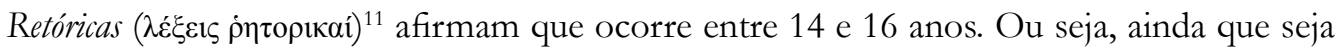
difícil estabelecer uma idade precisa, podemos imaginar que Xenofonte figura um Héracles com aproximadamente 15 anos de idade, num período da vida que hoje chamaríamos de adolescência.

\subsection{Dados na obra de Basílio sobre a idAde dos ENDEREÇAdos}

Contudo, evidentemente, o que Xenofonte considera não necessariamente dá indícios diretos para a idade dos endereçados por essa fala de Basílio. Vamos ver o que o autor diz, no texto, sobre seu público e em outras passagens de sua obra sobre as idades do homem. Em primeiro lugar, neste próprio texto, o autor chama o público de “ $\pi \alpha i \tilde{\delta} \varepsilon \zeta$ ” em duas ocasiões. Bem no começo: "Filhos, muitos são os motivos que me chamam para aconselhar vocês, motivos que julgo serem os melhores e que creio que muito hão de contribuir para vocês, se seguirem;"12 e no começo da segunda seção: "Nós, filhos, consideramos esta vida humana não ser de modo algum importante". ${ }^{13}$

O primeiro e óbvio significado de $\pi \alpha \tilde{i} \delta \varepsilon \varsigma$ é “crianças”, o que colocaria o público em uma idade ainda menor do que aquela determinada anteriormente, ou, mais precisamente, exatamente no limite entre a infância e a idade adulta. Nas suas Homilias sobre os Salmos, Basílio expõe de maneira clara sua divisão entre as idades:

É possível perceber, de modo geral, em todo o gênero humano como a utilidade do salmo atinge a todos. Pois, de fato, em mudança presente e futura estão sem sequer conservar a mesma condição do corpo, sem estar sequer fixos na mesma opinião, mas mudam o corpo de acordo com as transformações das idades, e transformando o pensamento à medida das variâncias das ocasiões. Pois, de fato, uns de nós somos crianças, outros adolescentes, e outros ainda são adultos, e ao envelhecermos novamente nos transformamos completamente. ${ }^{14}$

Ou seja, ele indica o quadro básico de idades que podemos ver na cultura grega

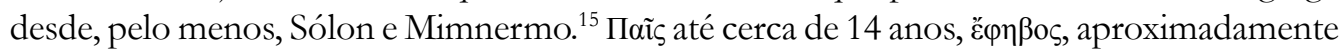
ao setênio seguinte, até os 21 , e ảví $\rho$, para a idade adulta. Nesse sentido, como em muitos

\footnotetext{
${ }_{11}$ Anecdota Graeca, p. 255.

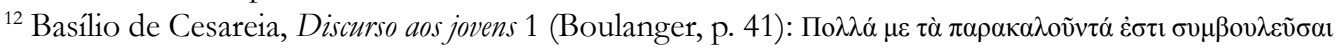

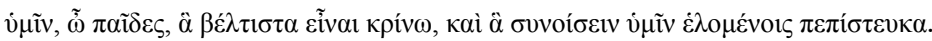

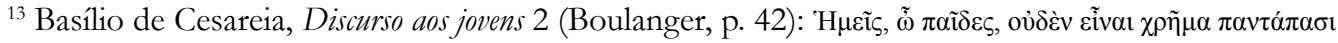

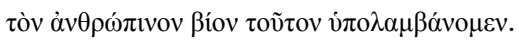

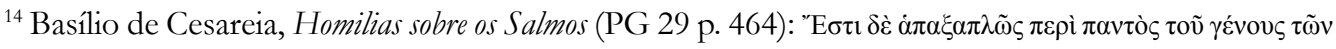

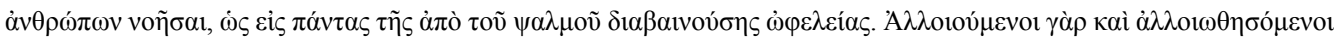

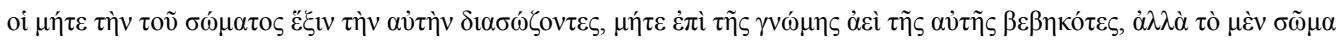

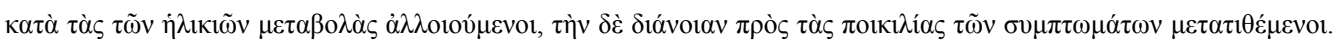

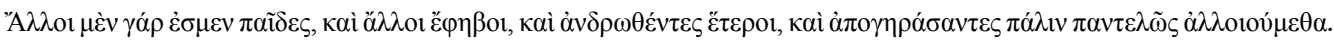

${ }^{15}$ Fr. 27 W. Uma análise desses fragmentos pode ser vista em Assunção, 2003.
} 
outros, os autores cristãos não se afastam muito dos pressupostos culturais já estabelecidos na cultura clássica.

Mas uma segunda leitura pode ser feita para esse $\pi \alpha i \delta \delta \varepsilon$ : ele representa o rebanho que o pastor é encarregado de cuidar. Nesse sentido, o pastor se coloca em posição paterna diante do rebanho. Assim, a forma $\pi \alpha \tilde{\delta} \delta \varepsilon \varsigma$ seria uma versão aticizante do $\tau \dot{\varepsilon} \kappa v ı \alpha$ que aparece no corpus joanino do Novo Testamento, e é frequentemente traduzido como "filhinhos."16 Com efeito, encontramos um uso seguro dessa expressão em outro lugar do corpus homilético de Basílio: "que isso não aconteça com vocês, meus filhos, que gerei através do evangelho, que eu embalei através da bênção das mãos". ${ }^{17}$

Ambas as leituras não são mutuamente excludentes; Basílio expressa ao mesmo tempo seu cuidado pastoral para um grupo de jovens adolescentes, que estão saindo da infância e entrando em contato com o mundo das letras pagãs. De fato, há outros indícios que confirmam isso.

Podemos ver outro dado que nos permite precisar o público endereçado por Basílio. Ao final da primeira seção de seu Discurso, Basílio nos informa: "Não se admirem que eu diga ter descoberto algo de proveitoso da minha parte para vocês, que frequentam o professor todo dia, e convivem com os antigos autores eloquentes através das palavras que deixaram". ${ }^{18}$

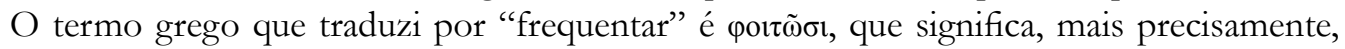
ir e vir, dando a noção de visitar um mestre de escola. Como Petit notou, esse é um dos principais termos técnicos para aluno (Petit, 1957, p. 20), e inclusive é a palavra que vai

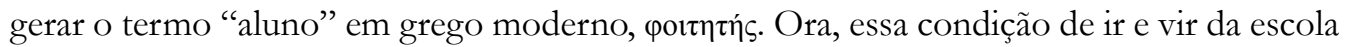
para a casa é particular daquilo que Marrou chamou de "ensino secundário" (Marrou, 1991, p. 251-74), que era conduzido, como ele nos afirma, em escolas privadas, majoritariamente locais (Marrou, 1991, p. 226).

A frase acima citada do Discurso de Basílio também é preciosa por nos dar mais uma informação que nos permite precisar ainda melhor o tipo de estudante com o qual ele

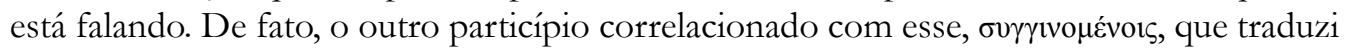
como "convivem", significa mais propriamente, de acordo com o Liddell Scott, "associar-se com”, “acostumar-se com”. Essa imagem pressupõe que esses alunos estão em constante contato com os antigos poetas e prosadores. Tal imagem vai ao encontro justamente dessa visão desses alunos como "estudantes secundaristas". Como afirma novamente H-I. Marrou,

\footnotetext{
${ }^{16}$ Jo 13, 33; 1 Jo 2, 1; 1 Jo 2, 12; 1 Jo 2, 28; 1 Jo 3, 7; 1 Jo 3, 18; 1 Jo, 4, 1; 1 Jo 5, 21 . O termo também aparece em uma carta de Paulo, Gl 4, 19. Não vou elencar todas as ocorrências mais comuns do

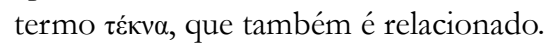

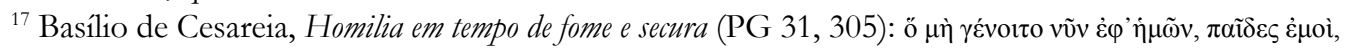

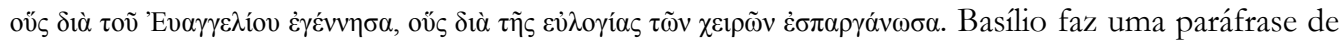
1 Co 14, 5.

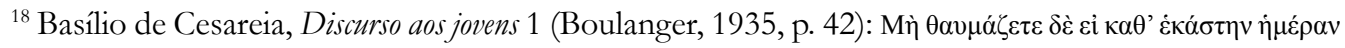

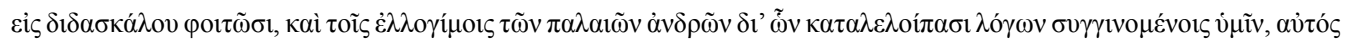

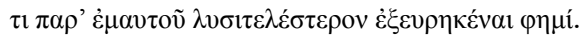


os secundaristas fazem "o estudo aprofundado dos poetas e de outros escritores clássicos" (Marrou, 1991, p. 253).

Isso é diferente da etapa seguinte, chamada por Marrou de "ensino superior". A "rainha" dessa etapa do currículo, segundo a expressão de Laurent Pernot (2015, p. 145), era a retórica, que, de fato, era a carreira mais seguida e de maior prestígio. Trata-se inclusive da educação que Basílio teve, tendo ele próprio frequentado alguns dos sofistas mais famosos de sua época.

O aspecto característico da educação retórica não é a leitura de textos clássicos, mas sim a execução de exercícios preparatórios, chamados $\pi \rho 0 \gamma v \mu v \alpha ́ \sigma \mu \alpha \tau \alpha$, e o posterior exercício, $\mu \varepsilon \lambda \varepsilon \dot{\tau} \tau$, ou declamatio em latim, que consistia na declamação de discursos fictícios para o derradeiro aprimoramento do orador (Marrou, 1991, p. 309). ${ }^{19}$ Naturalmente, o uso dos autores clássicos é o guia definitivo do exercício oratório, mas o estudante nessa fase de ensino está muito mais voltado ao exercício de criação do que no de familiarizar-se com os autores clássicos, que é o que a expressão de Basílio indica.

Uma outra indicação que Basilio nos dá é que ele já pressupõe o conhecimento do seu público dos versos de Hesíodo que ele parafraseia, a saber, os versos 293 a 297 dos Trabalhos e Dias:

Portanto, se vocês receberem as palavras de bom grado, haverão de ser da segunda ordem de pessoas elogiadas por Hesíodo, se não, eu não diria nada desagradável. Vocês evidentemente se lembram dos versos, nos quais ele diz que o melhor é quem compreende por si mesmo o que é necessário, bom também é aquele que segue as indicações de outros, aquele que não se adequa a nenhum dos dois é inútil para tudo. ${ }^{20}$

Com efeito, Basílio não anuncia um conhecimento novo, mas apenas diz $\mu \dot{\varepsilon} \mu v \eta \sigma \theta \varepsilon$, que traduzi como "vocês [...] se lembram". Daí se deve depreender que as pessoas com quem ele fala já frequentam a escola há algum tempo a ponto de provavelmente terem conhecimento de alguns autores canônicos. Essa pressuposição de conhecimento é reforçada pela locução adverbial $\delta \eta \lambda$ ovótı.

A explicação para isso não é porque seu público já está totalmente avançado nos estudos secundários, mas porque, como nos indica o próprio Marrou (1991, p. 256), referendado em uma tábua de cera de um estudante de Palmira (Hesseling, 1893, p. 302), Hesíodo já se fazia presente no ensino desde o primário, sobretudo por suas máximas morais contidas nos Trabalhos e Dias.

${ }^{19}$ Isso se trata evidentemente de uma simplificação para facilitar a argumentação. Nas Instituições Oratórias de Quintiliano, livro II, capítulo 1, podemos ver uma interessante discussão sobre a fronteira entre as duas disciplinas.

${ }^{20}$ Basílio de Cesareia, Discurso aos jovens 1 (Boulanger, 1935, p. 41): Ei $\mu \varepsilon \dot{\varepsilon v ~ o u ̃ v ~ \pi \rho o \theta v ́ \mu \omega \varsigma ~ \delta \varepsilon ́ \chi o เ \sigma \theta \varepsilon ~ \tau a ̀ ~} \lambda \varepsilon \gamma o ́ \mu \varepsilon v \alpha$,

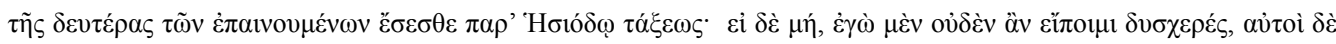

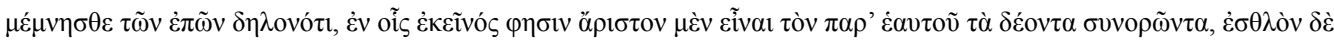

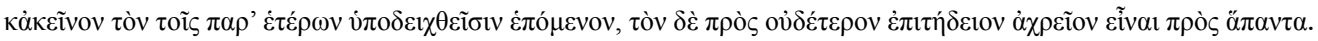


Disso se pode concluir que são estudantes frequentando o ensino secundário e que já possuem uma espécie de bagagem mínima, não necessariamente adquirida na etapa que estão cursando, mas que faz uso de alguns conhecimentos que já são adquiridos do ensino básico. $^{21}$

Um outro comentário importante sobre o endereço desse discurso aparece em um momento seguinte do tratado. Basílio comenta sobre a segunda vida, depois da terrestre, mas ele interrompe a discussão e rejeita o assunto com base em dois pontos: "Que vida é essa e onde e como a viveremos, chega a um ponto mais trabalhoso do que a presente missiva, e é para ouvintes mais velhos do que vocês". ${ }^{22}$ Essa rejeição é feita com base na extensão do texto e também na idade dos ouvintes. Ou seja, não se trata de estudantes adultos, mais velhos, mas sim de pessoas bastante jovens, que ainda não estão à altura dos ensinamentos profundos da religião. Isso é mais congruente com a ideia dos jovens entre 14 e 16 anos que vimos acima e não com estudantes adultos de retórica.

Mais um dado nos permite verificar que Basílio considera os jovens de sua carta não apenas pessoas em desenvolvimento intelectual, mas também ainda passando por estágios de maturação moral. Mais à frente, ele afirma: "não é pequeno o proveito de gerar nas almas dos jovens uma certa familiaridade e hábito da virtude; mas, dado que tais ensinamentos são naturalmente irremovíveis, quando são marcados profundamente nas almas ainda tenras". ${ }^{23}$

Essa imagem deixa ainda mais claro de que grupo de pessoas Basílio fala, se não em termos de uma idade precisa, ao menos em termos de seu modo de ser e de sua maturidade mental. Não são, de fato, jovens adultos já formados, mas um grupo ainda em formação, que não solidificou seu caráter. Com efeito, a própria expressão que Basilio escreveu, ả $\mu \varepsilon \tau \alpha ́ \sigma \tau \alpha \tau \alpha$, é um eco de uma discussão semelhante que encontramos na República de Platão. ${ }^{24}$

$\mathrm{Na}$ passagem referenciada de Platão, o filósofo ateniense afirma que, devido à incapacidade intelectual dos mais jovens, eles não deveriam receber os textos dos poetas

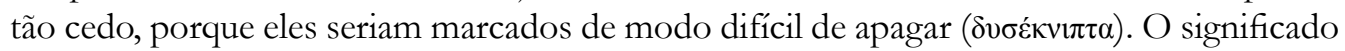
é curiosamente o oposto do dado por Basílio. O bispo de Cesareia, afinal, disse que os exemplos de virtude devem ser dados a jovens dessa idade porque, desse modo, eles ficariam marcados em suas almas. Mas, apesar dessa diferença no sentido da afirmação, a lógica que subjaz a ambas afirmações é a mesma: são jovens, talvez chamemos até de crianças, ainda em formação moral, e a alma deles ainda é bastante receptiva às impressões deixadas pelos textos dos poetas e, no caso de Basílio, ele afirma também explicitamente as influências de prosadores e filósofos.

\footnotetext{
${ }^{21}$ Moffat (1972) chega a uma conclusão parecida, sem distinguir precisamente do ensino mais avançado. Outros autores, como van Dam (2002), parecem não ter percebido a questão da idade dos alunos e tratam como se fossem jovens adultos.

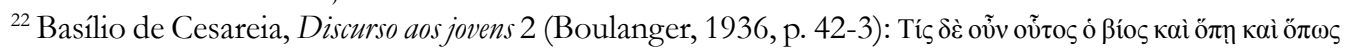

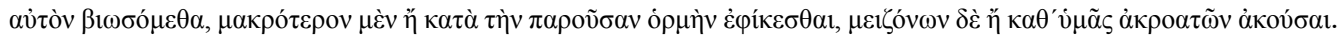

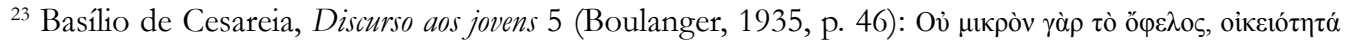

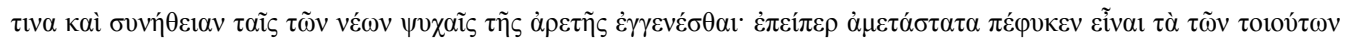

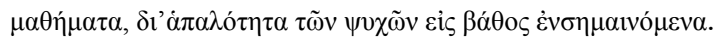

${ }^{24}$ Platão, República, 378e.
} 
Essa ideia, a partir pelo menos da República, tornou-se lugar comum em textos que falam do desenvolvimento infantil. Plutarco, em seu tratado Sobre a educação das crianças, dá admoestações semelhantes. Como ele afirma:

Tal como é necessário moldar os membros do corpo dos filhos logo no nascimento, para que eles cresçam eretos e aprumados, do mesmo modo, convém regrar os costumes dos filhos desde o início. Flexível

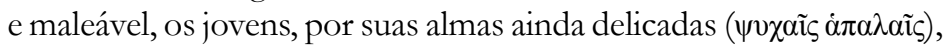
absorvem as lições. Tudo que é rígido dificilmente se flexibiliza. Como os sinetes imprimem-se na cera amolecida, assim as lições marcam a alma dos ainda infantes. Parece-me que Platão, o enviado dos deuses, aconselha às amas de leite moderadas que não relatem histórias aleatórias às crianças, para que não tenham suas almas preenchidas desde o início por ignorância e corrupção. ${ }^{25}$

Alguns comentadores ${ }^{26}$ chegaram até a sugerir esse texto como sendo o modelo no qual Basílio se baseou para a sua composição. Enquanto certamente se trata do mesmo gênero literário, não há nenhuma similaridade lexical aprofundada entre os textos que indique a proveniência. $\mathrm{Na}$ verdade, há mais proximidade lexical com o texto de Platão do que com o de Plutarco, ainda que exatamente qual acesso Basílio tinha à República é um assunto que requer um estudo aprofundado.

\subsection{A QUESTÃo DA MATURIDADE INTELECTUAL PARA A LEITURA BÍBLICA}

A questão alcança seu ponto mais importante quando ele fala sobre os textos sagrados: "Mas enquanto não for possível compreender a profundidade de seu pensamento, por causa da idade". ${ }^{27}$ Ou seja, o público para o qual Basílio se dirige ainda não atingiu totalmente a capacidade de compreender a Bíblia. Que capacidade seria essa, moral ou intelectual?

Philip Rousseau é da opinião de que é uma capacidade moral (Rousseau, 1998, p. 53). Ele julga que o opúsculo de Basílio é um texto feito para justificar uma cosmovisão cristã sem o recurso aos textos canônicos da religião (Rousseau, 1998, p. 47). Certamente, Basílio está empreendendo uma investigação acerca da universalidade dos valores morais,

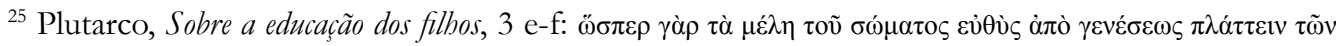

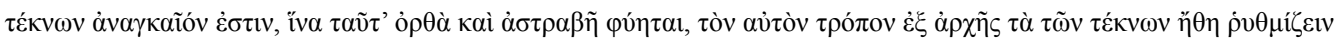

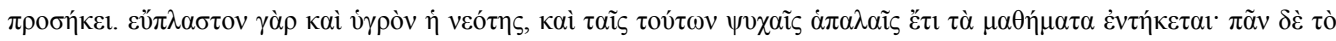

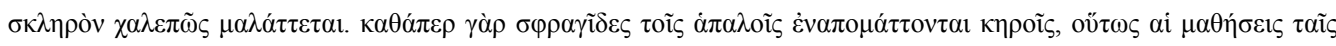

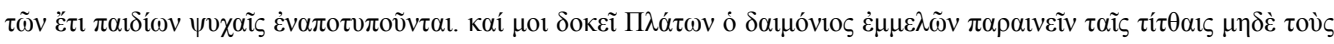

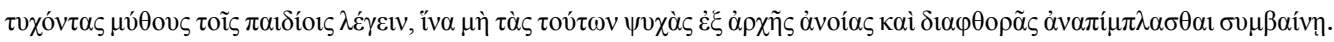
Tradução de Maria Aparecida de Oliveira Silva.

${ }^{26}$ Como Moffat (1972) e o próprio editor Boulanger (1935).

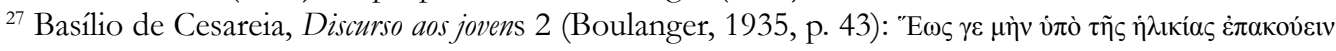

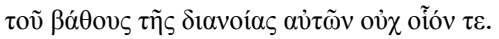


ou pelo menos da comunidade entre os valores da Bíblia e das letras gregas, como veremos mais à frente. No entanto, lembremos que Orígenes, no seu quarto livro Sobre os Princípios, fala na diversidade de significados da Bíblia e como a primeira leitura é atribuída aos mais

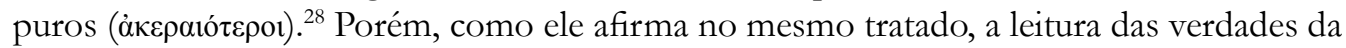
religião é mais profunda e apenas se encontra entre aqueles mais avançados, que realizam a chamada leitura espiritual.

Essa visão da existência de várias leituras é o padrão de Orígenes, e em algumas passagens, como no seu Comentário ao Evangelho de João, ele indica a possibilidade de esses mais simples realizarem leituras equivocadas e, por isso, se desviarem do caminho. ${ }^{29} \mathrm{Ou}$ seja, a simplicidade da mente de uma pessoa, para Orígenes, pode ser um entrave para a real compreensão das escrituras.

E o que Orígenes tem a ver com Basílio? A importância da visão origenista de paideia no Discurso aos jovens já foi destacada por Naldini (1976, p. 381), mas foi justamente Basílio de Cesareia que nos possibilitou a preservação do quarto livro Sobre os Princípios em grego ao editar, conjuntamente com seu colega Gregório de Nazianzo, a coleção origenista chamada de Filocália..$^{30}$ Ou seja, a visão exegética de Basílio é fortemente influenciada por Orígenes. ${ }^{31}$ Assim, não é de todo implausível que os limites à compreensão das escrituras sejam também intelectuais e que parte do que limita a compreensão seja a efetiva maturação intelectual, que os estudos inclusive favorecem.

\section{Por que Basílio admite a leitura dos textos clássicos?}

Isso nos leva para a segunda indagação deste artigo, que tem de ser vista em conexão direta com a primeira questão que levantei a respeito da idade. Quais são os motivos que levam Basílio a recomendar o contato com textos clássicos e a razão que é dada. Como

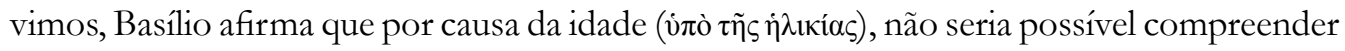
o pensamento (biavoías).

O termo citado tem grande importância no pensamento de Basílio, de seu irmão, Gregório de Nissa, e de seu colega, Gregório de Nazianzo. Com efeito, ele possui dois significados básicos. O primeiro é o do ato de raciocínio. É o termo que os padres capadócios usam para representar o raciocínio humano em sua capacidade especulativa. Vemos o Nisseno afirmar o seguinte: "quem há de me dar aquelas asas para ser capaz nas alturas da grandeza

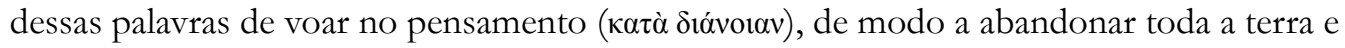
atravessar todo o ar que está difuso no meio?". 32

\footnotetext{
${ }^{28}$ Orígenes, Sobre os Princípios, 4, $2,2$.

${ }^{29}$ Orígenes, Homilias sobre o Evangelho de João, XIII, 39.

${ }^{30}$ Sobre as dúvidas a respeito da autoria ver a introdução de Harl à edição da Sources Chrétiennes.

${ }^{31}$ Sobre a influência de Orígenes em Basílio, ver Rousseau (1998, p. 11-4).

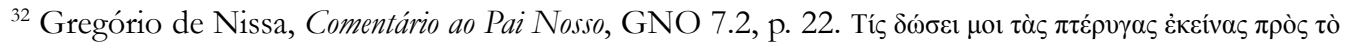

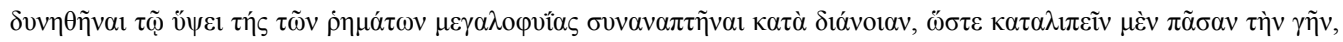

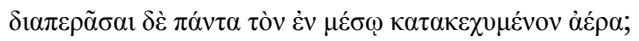


Ou seja, no trecho citado, Gregório faz uma proposição de algo que modernamente chamaríamos de "exercício de pensamento", recomendando a tentativa de perceber as realidades superiores. O termo utilizado é sióvoı, que tem significados muito diferentes de autor para autor, ${ }^{33}$ mas, para Gregório de Nissa, de acordo com a descrição feita por Martin Lard, podemos precisar como "pensamento humano" (Laird, 2004, p. 30ss). Do mesmo modo, vemos o mesmo sentido presente na Segunda Oração Teológica de Gregório de Nazianzo: "Vamos lá, ao deixar a terra e aquilo que está a sua volta, e fique mais leve com as asas do

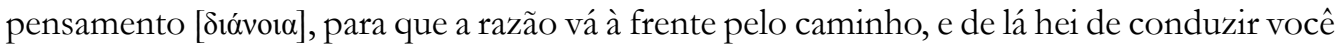
aos espetáculos celestes, o próprio céu e o que está além dele". 34

No entanto, um sentido derivado dessa palavra podemos encontrar já em Orígenes, que é da Sióvora como o sentido não evidente de um texto, mas o sentido que deve ser compreendido dele. Podemos vê-la no alexandrino: "afirmamos, portanto, que a lei é dupla,

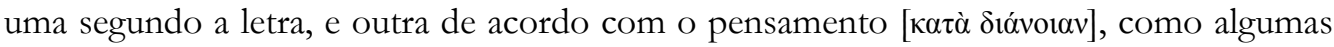
pessoas anteriores a nós já ensinaram". ${ }^{35}$ Gregório de Nissa também adota um significado

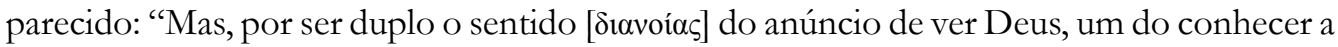
natureza que está acima de tudo, outro de ser dominado por ele através da pureza na vida". ${ }^{36}$ No último caso, preferi traduzir sióvoı como "sentido", dado que o significado intendido por Gregório é mais próximo de "sentido" do que de "pensamento".

Portanto, retornando ao texto de Basílio, podemos compreender melhor que ele pressupõe que os textos sagrados possuam um sentido mais profundo que os jovens secundaristas ainda não são totalmente capazes de compreender. Não se trata necessariamente de uma visão elitista, na qual os textos bíblicos seriam acessíveis apenas para uma elite de iniciados, mas sim, dada a interpretação da idade que já damos, que as pessoas demasiadamente jovens ainda não são capazes de compreender os textos sagrados; trata-se de uma questão de desenvolvimento intelectual e maturidade.

É por isso que ele visualiza os textos da literatura pagã como uma espécie de exercício para a aquisição das capacidades necessárias para a verdadeira compreensão dos textos sagrados, e ele compara com uma série de atividades que carecem de exercícios preliminares, como observar o sol por meio de sombras e espelhos, exercitar em danças antes de fazer exercícios táticos e os tingidores que em primeiro lugar alvejam o tecido antes de aplicar a cor

\footnotetext{
${ }^{33}$ Em Platão, ou, mais precisamente, na República, sióvoı é a faculdade intelectiva que, a partir dos objetos físicos, permite ao homem atingir o conhecimento das realidades estáveis (Cooper, 1966). Em Plotino o ponto de vista muda, e a dióvoı é vista como o afastamento e individuação do Intelecto em corpo humano, é o pensamento humano comum (Aubry, 2016).

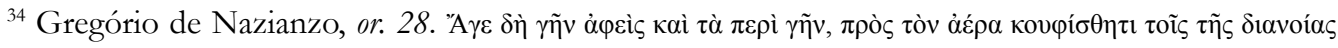

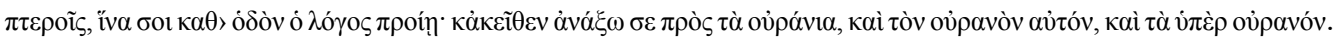

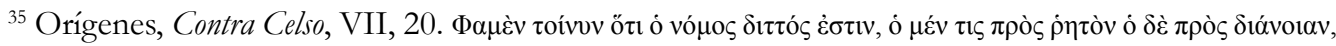

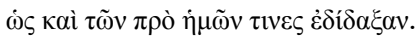

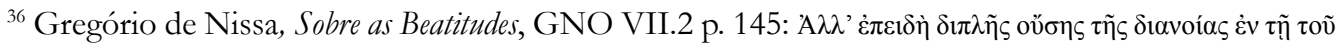

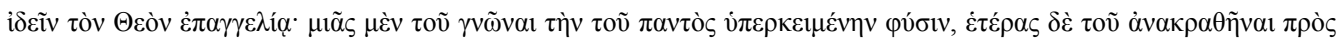

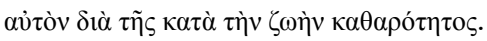


desejada. ${ }^{37}$ Em um momento posterior, ele compara os esforços necessários para o cristão com os atletas, que se ocupam em esforços pesadíssimos para a obtenção da vitória. ${ }^{38}$ Assim, o contato com as letras gregas é comparado a essa atividade preparatória de atletas e músicos.

\subsection{Os PROBLEMAS CONTIDOS NOS TEXTOS CLÁSSICOS}

Todos esses benefícios não são completamente gratuitos, e uma parte, ainda que bem pequena, do tratado de Basilio é dedicada à admoestação sobre os perigos que essa literatura contém. Segundo o bispo de Cesareia, nem tudo que está presente nos poetas é benéfico, pois eles são muito diversos ( $\left.\pi \alpha v \tau o \delta \alpha \pi 0^{\prime}\right)$. Além disso, eles são especialmente nocivos porque junto com a beleza das palavras se imiscui o veneno perigoso do engano: "para que não, ao aceitarmos por causa do prazer das palavras, deixemos passar despercebido algo do pior, como os que consomem venenos junto com o mel" ${ }^{39}$ Essa imagem é encontrada de modo ainda mais claro em um opúsculo de Plutarco, Sobre como o jovem deve ler os poetas. Segundo Plutarco, explicando de modo mais compreensivo do que neste trecho de Basílio, os poetas desejam agradar e, ao fazerem isso, inserem muitas doutrinas e ideias equivocadas. ${ }^{40}$

Em face a todas essas questões, o bispo de Cesareia comenta: "portanto, não vamos elogiar os poetas em tudo, nem quando imitam pessoas que insultam, ralham, são luxuriosas ou beberronas, nem quando definem a felicidade por uma mesa repleta e odes cantadas". ${ }^{41}$

Esse catálogo não é original. $\mathrm{Na}$ verdade, ele remete à discussão entre Sócrates e Adimanto presente no livro II da República, ${ }^{42}$ em que Platão faz uma descrição mais aprofundada da maior parte desses itens colocados por Basílio. Mais especificamente cristão e, provavelmente, da autoria do bispo é o comentário que vem na sequência: "E menos de tudo prestaremos atenção quando conversam algo sobre deuses, sobretudo quando narram sobre muitos deles, que nem sequer estão de acordo entre si”. ${ }^{43}$

\subsection{A virtude e os textos clássicos}

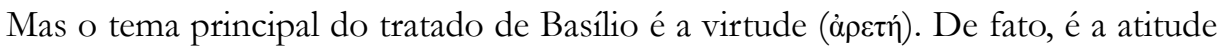
favorável dos escritos gregos à noção de virtude que fornece o principal mote de todo o tratado, entabulando uma série de exempla clássicos a respeito da utilidade e da respeitabilidade

\footnotetext{
${ }^{37}$ Basílio de Cesareia, Discurso aos jovens 2 (Boulanger, 1935, p. 43).

${ }^{38}$ Basílio de Cesareia, Discurso aos jovens 8 (Boulanger, 1935 p. 52-4).

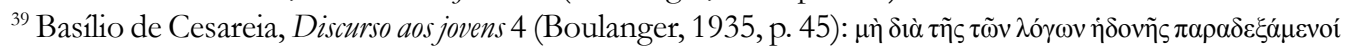

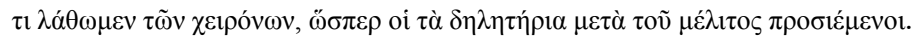

${ }^{40}$ Plutarco, Sobre como o jovem deve ler os poetas, $16 \mathrm{~b}$.

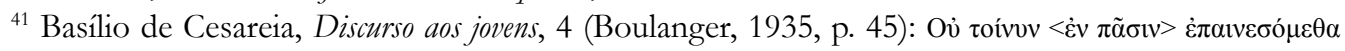

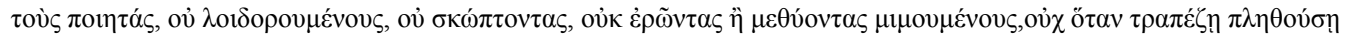

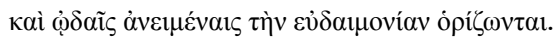

${ }^{42}$ Platão, República, 377e-378d.

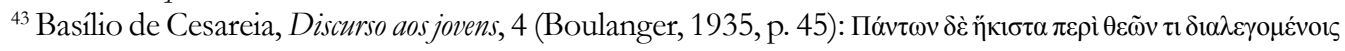

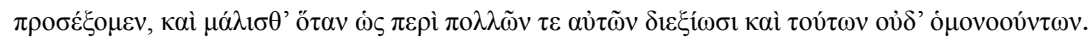


de homens virtuosos. Nessa passagem, que é a seção mais longa de todo o Discurso, vemos Basílio exercitar de forma bastante evidente sua formação retórica, mostrando a profundidade de seu repertório de $\chi \rho \varepsilon_{i ́ a}{ }^{44}$ para solidificar essa tese de que os textos clássicos fornecem modelos de virtude que devem ser copiados pelos jovens.

A tese principal do bispo de Cesareia é de que os textos gregos - ele diz explicitamente que a filosofia é mais copiosa neste ponto - fornecem modelos de grande proveito para a imitação dos jovens. Se essa ideia é somada à que já vimos da visão dessa etapa como um treino e uma preparação - um tema que Basílio vai explorar de forma mais completa na seção 9 desse opúsculo -, é possível formar uma noção mais precisa da visão do autor sobre a questão. Como a participação no sistema educacional é inevitável, deve-se escolher o que

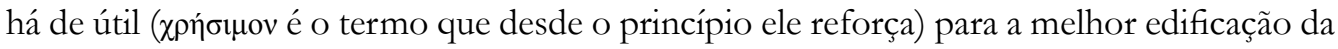
pessoa enquanto ela ainda não tem a capacidade de compreender profundamente os textos e as doutrinas santas da Igreja.

\section{O CONTEXTO HISTÓRICO E SUA RELEVÂNCIA PARA A COMPREENSÃo DA INTENÇÃo DE Basílio}

Portanto, o Discurso aos jovens de Basílio de Cesareia é um texto profundamente calcado na realidade histórica do autor. Em primeiro lugar é importante notar como o contexto histórico é fundamental. Como Marrou indicou, os cristãos na Antiguidade não se preocuparam em formar uma estrutura pedagógica alternativa e se contentaram com a utilização do sistema escolar da cultura pagã (Marrou, 1991, p. 490). Isso criou uma situação um pouco anômala, em que as crianças cristãs estavam em contato estreito com uma literatura que, naquela época, estava profundamente ligada à religião antiga. Ainda mais se considerarmos o movimento que, a partir de Jâmblico e atingindo seu apogeu com o imperador Juliano e depois Proclo, foi paulatinamente fazendo a religião pagã adotar a literatura grega como texto sagrado. ${ }^{45}$

Dessa maneira, o Discurso aos jovens torna-se um texto necessário para justificar, ou mesmo permitir, a presença de jovens cristãos no sistema educacional da Antiguidade, sem a qual não seria possível sequer que ocupassem qualquer cargo dentro da administração imperial (Watts, 2008, p. 7). Isso corresponde a uma resposta específica em um contexto muito particular da Antiguidade Tardia; Basílio não tinha pretensões de dar uma resposta universal ao problema do relacionamento entre o Cristianismo e as culturas pagãs. Como van Dam afirma, Basílio pressupõe que os jovens em tempo haverão de migrar dos estudos seculares para ter um contato mais aprofundado com as Sagradas Escrituras (Van Dam, 2002, p. 182). Isso certamente permite que Basilio tenha uma atitude mais leniente e bem

\footnotetext{
${ }^{44}$ Como diz Pernot (2015, p. 147): "Anecdote (khreia). The anecdote is a saying or a deed, short and meaningful, attributed to a famous person".

${ }^{45}$ Sobre o relacionamento entre Juliano e Jâmblico, ver Finamore (1998). Sobre a transformação da poesia em escritura, fato que talvez se realize completamente apenas com Proclo, já uma geração posterior a Basílio, ver Chlup (2012, p. 185-90).
} 
pouco crítica em relação à literatura pagã. Em outros contextos culturais é possível imaginar reações e comentários distintos.

\subsection{Outras REaÇões}

Podemos ver uma situação completamente diferente numa obra de seu irmão Gregório, o Diálogo sobre a alma e a ressurreição. O texto, que é a conversa entre dois dos irmãos de Basílio, após a sua morte, Macrina e o próprio Gregório, é a obra do Nisseno que mais se ocupa com comentários aos pensadores "de fora" ( $\tau \tilde{\omega} \nu \check{\varepsilon} \xi \omega)$. Em uma passagem em que Gregório expõe suas inseguranças sobre o futuro da alma depois da morte, Macrina responde com a seguinte interjeição: “deixa para lá, ela diz, essas lorotas de fora ( nas quais o descobridor da mentira elaborou as suposições enganosas para o prejuízo da verdade." 46

A irmã de Basílio e Gregório não realizou uma crítica absoluta à filosofia pagã e em outros momentos ela irá elogiar algumas posições filosóficas, mas, em última instância, a filosofia será rejeitada nesse tratado como incapaz de atingir a verdade e conseguir definir a alma corretamente. ${ }^{47}$

Ou seja, em outros contextos e situações, seria bem provável que Basílio refletisse uma posição mais crítica, parecida com a que é exposta no Diálogo entre seus irmãos. Mas o que está em questão no Discurso aos jovens é o valor educacional e propedêutico da cultura clássica.

Dessa maneira, ele acabou por admitir que há uma comunidade entre a literatura grega e o Cristianismo e que aquela pode servir de preparação para os jovens no período em que eles estão adquirindo a maturidade moral e intelectual necessária para compreenderem a profundidade dos mistérios cristãos. Trata-se de uma asserção não completamente em desacordo com as atitudes de outros autores cristãos que lhe antecederam, mormente Clemente de Alexandria e Justino, mas não totalmente presente na literatura cristã anterior, que viu autores com posições bem mais hostis. ${ }^{48}$ A posição de Basílio calhou por ter efeitos perenes na visão que o Cristianismo teve sobre a literatura clássica. ${ }^{49}$

\footnotetext{
${ }^{46}$ Gregório de Nissa, Diálogo sobre a alma e a ressurreição. GNO III.3, p. 6.

${ }^{47}$ Idem, p. 33-34.

${ }^{48} \mathrm{Um}$ texto brasileiro sobre o conflito entre os cristãos do segundo e terceiro século e o mito grego é o de Jacyntho Brandão (2014).

${ }^{49}$ Nas palavras de Werner Jaeger (1991, p. 105, n. 12) este opúsculo "foi sempre a autoridade máxima sobre a questão do valor dos estudos clássicos para a Igreja”.
} 


\section{REFERÊNCIAS}

\section{Literatura Primária}

ANECDOTA GRAECA. Volumen primum. Lexica segueriana (Ed. Immanuel Bekker). Berlin: Nauck, 1814.

BASIL OF CAESAREA; WILSON, N. G. Saint Basil on the value of Greek literature. London: Duckworth, 1975.

Saint BASILE. Aux jeunes gents sur la manière de tirer profit des lettres helléniques. Paris: Les Belles Lettres, 1935.

BASILIO DI CESAREA; NALDINI, M. Discorso ai giovani (Oratio ad adolescentes) Biblioteca Patristica 3 (ed. Naldini, M.). Firenze: Nardini, 1984.

BASILIUS CAESAREAE. Opera omnia quae exstant, vel quae sub ejus nomine circumferuntur Tomus Primus (Patrologia Graeca 29). Paris: J-P. Migne, 1857.

BASILIUS CAESAREAE. Opera omnia quae exstant, vel quae sub ejus nomine circumferuntur Tomus Tertius (Patrologia Graeca 31). Paris: J-P. Migne, 1857.

DELECTUS ex iambos et elegis graecis (ed. M. L. West). Oxford: Clarendon Press, 1980.

ETYMOLOGICUM MAGNUM seu verius lexicon saepissime vocabulorum origines indagans ex pluribus lexicis scholiastis et grammaticis. Anonymi cuiusdam opera concinnatum. (Gaisford, T. ed). Oxford: Typographeus Academicus, 1848.

GRÉGOIRE DE NAZIANZE. Discours 27-31 (Sources Chrétiennes 250). Paris: Éditions du Cerf, 1978.

GRÉGOIRE DE NYSSE. Homélies sur Notre Père. Introduction, traduction e notes par M. Cassin et Ch. Boudignon. Paris: Éditions du Cerf, 2018.

GREGÓRIO DE NISSA. Comentário ao pai nosso. Introdução, tradução e notas por Bruno S. Gripp. Petrópolis: Paideusis, 2018.

GREGORII NYSSENI Dialogus de anima et resurrectione. Opera dogmática minora, pars III. Leiden; Boston: Brill, 2014. (Gregorii Nysseni Opera, v. 3 no. 3, ed. Andrea Spira).

GREGORII NYSSENI De Oratione Domenica, De Beatitudinibus. Leiden; New York; Köln: Brill, 1992. (Gregorii Nysseni Opera, v. 7, n. 2, ed. John Callahan).

NOVUM TESTAMENTUM GRAECE post Eberhard Nestle et Erwin Nestle communiter ediderunt Kurt Aland, Matthew Black, Carlo M. Martini, Bruce M. Metzger, Allen Wikgren apparatum criticum recensuerunt et editionem novis curis elaboraverunt Kurt Aland et Barbara Aland una cum Instituto studiorum textus Novi Testamenti Monasteriensi (ed. 26). Stuttgart: Deutsche Bibelgesellschaft, 1979.

ORIGÈNE. Commentaire sur Saint Jean tome III livre XIII. Texte Grec avant-propos, traduction et notes par Cécile Blanc. Paris: Les Éditions du Cerf, 1975. 
ORIGÈNE. Contre Celse. Ed. Marcel Bourret. Paris: Les Éditions du Cerf, 1967-1976. t. 1-5. (Sources Chrétiennes, n. 132, 136, 147, 150, 227).

ORIGÈNE. Philocalie 1-20 Sur les écritures. Introduction, text, traduction et notes par Marguerite Harl. Paris: Les Éditions du Cerf, 1993. (Sources Chrétiennes, 302).

ORIGÈNE. Traité des principes. Ed. H Crouzel, M. Simonetti. Paris: Les Éditions du Cerf, 1978-80. 4 v.

ORÍGENES. Tratado sobre os princípios. Trad. João Eduardo Lupi. São Paulo: Paulus, 2017.

ORIGENES. Werke: fünfter band. Die Griechischen Christlichen Schriftsteller der ersten drei Jahrhunderte, ed. Paul Koetschau. Leipzig: J. C. Hinrich, 1913.

PLATO. Platonis opera tomus V: Respublica. Ed. John Burnet. Oxford: Clarendon Press, 1978.

PLUTARCHUS. Moralia. Ed. W. R. Paton. Leipzig: Teubner, 1993. v. 1.

PLUTARCO. Da educação das crianças. Trad. Maria Aparecida de Oliveira Silva. São Paulo: Edipro, 2015.

QUINTILIAN. Institutio oratoria. Book. 2. Edited by Tobias Reinhard and Michael Winterbottom. Oxford: Oxford University Press, 2006.

XENOPHON. Memorabilia, Oeconomicus, Symposium, Apology. Translated by E. C. Marchant and O. J. Todd. Cambridge, MA/London: Cambridge University Press, 1997.

\section{Literatura SECUNDÁRIA}

ASSUNÇÃO, T. Nota sobre a correção de Mimnermo por Sólon (26 G. e P.). Classica, v. 15/16, p. 51-62, 2003. DOI: https://doi.org/10.24277/classica.v15i15/16.228

AUBRY, G. Metaphysics of soul and self in Plotinus. In: REMES, Pauliina; SLAVEVAGRIFFIN, Svetla (Ed.). The Routledge Handbook of Neoplatonism. London: Routledge, 2014, p. 310-22.

BACKUS, I. The church fathers and the humanities in the Renaissance and the Reformation. In: ZIMMERMANN, Jens (Ed.). Re-envisioning christian humanism: education and the restauration of humanity. Oxford: Oxford University Press, 2017, p. 33-54.

BALTHASAR, H. U. Présence et pensée: essaie sur la philosophie religieuse de Grégoire de Nysse. Paris: Beauchesne, 1942.

BRANDÃO, J. Em nome da (in)diferença: o mito grego e os apologistas cristãos do segundo século. Campinas: Unicamp, 2014.

CHLUP, R. Proclus, an introduction. Cambridge: Cambridge University Press, 2012.

COOPER, N. The importance of dianoia in Plato's theory of forms. Classical Quarterly, v. 16 , p. 65-9, 1966. 
van DAM, R. Kingdom of snow: Roman rule and Greek culture in Cappadocia. Philadelphia: University of Pennsylvania Press, 2002.

DANIÉLOU, J. Platonisme et théologie mystique: doctrine spirituelle de saint Grégoire de Nysse. Paris: Aubier, 1944.

DANIÉLOU, J. Message évangélique et culture bellénistique aux IIe et IIIe siècles, Histoire des doctrines chrétiennes avant Nicée. Tournai: Desclée, 1961. v. 2.

ESPER, M. Enkomiastik und Christianismos in Gregors epideiktischer Rede auf den Heiligen Theodor. In: SPIRAS, Andreas (Ed.). The biographical works of Gregory of Nyssa: Proceedings of the Fifth International Colloquim on Gregory of Nyssa. Philadelphia: Philadelphia Patristics Foundation, 1982, p. 145-60.

FEDWICK, P.J. The translations of the works of Basil before 1400. In: (Ed.). Basil of Caesarea, Christian, humanist, ascetic: A sixteen bundredth anniversary symposium. Toronto: Pontifical Institute of Mediaeval Studies, 1981, p. 439-512.

FINAMORE, J. F. Julian and the descent of Asclepius. Journal of Neoplatonic Studies, v. 7, n. 2, p. 63-86, 1998.

FORTIN, E. L. Hellenism and christianity in Basil the Great's Address Ad Adulescentes. In: BLUMENTHAL, H. J.; MARKUS, R. A. (Ed.). Neoplatonism and early Christian thought. London: Variorum Publications, 1981, p. 189-203.

HESSELING, D. C. On waxen tables with fables of Babrius (Tabulae Ceratae Assendelftianae). Journal of Hellenic Studies, v. 13, p. 293-314, 1892-3.

JAEGER, W. Cristianismo primitivo e paideia grega. Lisboa: Edições 70, 1991.

LAIRD, M. Gregory of Nyssa and the grasp of faith: union, knowledge and divine presence. Oxford: Oxford University Press, 2004.

LANGONE, H. Chorar por Dido é inútil: Santo Agostinho, Confissões, Literatura. São Paulo: Filocalia, 2018.

LUDLOW, M. Useful and beautiful: a reading of Gregory of Nyssa's 'On Virginity' and a proposal for understanding early Christian literature. Irish Theological Quarterly, v. 3, n. 79, p. 219-40, 2014.

MARROU, H-I. História da educação na Antiguidade. São Paulo: EPU, 1991.

MOFFAT, A. The occasion of St. Basil's Address to young men. Antichthon, v. 6, p. 74-86, 1972.

MÜHLENBERG, E. Die Philosophische Bildung Gregors von Nyssa in den Büchern Contra Euromium. In: HARL, Marguerite (Éd.). Écriture et culture philosophique dans la pensée de Grégoire de Nysse: actes du colloque de Chevetogne. Leiden: Brill, 1971, p. 230-54. 
NALDINI, M. Paideia origeniana nella 'Oratio ad adolescentes' di Basilio Magno. Vetera Christianorum, v. 13, p. 297-318, 1976.

NALDINI, M. Sulla ‘Oratio ad adolescentes’ di Basilio Magno. Prometheus, v. 4, p. 36-44, 1978.

PERNOT, L. Epideictic rhetoric: questioning the stakes of ancient praise. Austin: University of Texas Press, 2015.

PETIT, P. Les étudiants de Libanius: un professeur de faculté et ses élèves au Bas Empire. Paris: Nouvelles Éditions Latines, 1957.

RAHNER, H. Miti greci nell'interpretazione cristiana. Bologna: EDP, 2011.

ROUSSEAU, Ph. Basil of Caesarea. Berkeley; Los Angeles: University of California Press, 1998. VALGIGLIO E. Basilio magno Ad Adulescentes e Plutarco de Audiendis poetis. Rivista di Studi Classici, Torino, v. 23, p. 67-86, 1975.

WATTS, E. J. City and school in Late Antique Athens and Alexandria. Berkeley; Los Angeles; London: University of California Press, 2008. 